\title{
The impact of chronic pain on functionality and quality of life of the elderly
}

\author{
O impacto da dor crônica na funcionalidade e qualidade de vida de idosos
}

\author{
Bianca de Oliveira Lemos ${ }^{1}$, Ana Marcia Rodrigues da Cunha², Claudia Bernardi Cesarino ${ }^{3}$, Marielza Regina Ismael Martins ${ }^{4}$
}

DOI 10.5935/2595-0118.20190042

\section{ABSTRACT}

BACKGROUND AND OBJECTIVES: Chronic pain is one of the most common conditions found by health professionals in elderly and is associated with substantial impairment of reduced mobility, avoidance of activities, depression, sleep impairment and isolation. The objective of this study was to check the impact of chronic pain on the functionality and the quality of life of the elderly.

METHODS: It is a descriptive, cross-sectional and exploratory study with 20 patients attending the Pain Clinic of Hospital de Base de São José do Rio Preto. Twenty patients under the age of 60 were evaluated by the same instruments for comparative data. The instruments used were a semi-structured interview containing questions about sensory aspects, emotional and functional impact, sleep, attitudes and beliefs, coping style, treatment, expectation and objectives, and resources. The World Health Organization Quality of Life Assessment for Older Adults questionnaire was used to evaluate the quality of life and, to evaluate the functional capacity of daily life, the OARS, multidimensional functional assessment questionnaire. The pain was assessed by the Brief Pain Inventory.

RESULTS: A significant difference was observed between the domains of sensory abilities, autonomy and intimacy $(\mathrm{p}<0.05)$ in which the analyzed group presented worse values than the control, while the latter presented worse value in the domain of death and dying. In addition, there was a statistical difference between the groups in the instrumental activity of daily living and between the intensity of pain.

Bianca de Oliveira Lemos - (Dhttps://orcid.org/0000-0002-8665-734X;

Ana Marcia Rodrigues da Cunha - (Dhttps://orcid.org/0000-0001-9503-6337;

Claudia Bernardi Cesarino - Dhttps://orcid.org/0000-0002-8701-9163;

Marielza Regina Ismael Martins - (Dhttps://orcid.org/0000-0002-1140-7581.

1. Faculdade de Medicina de São Jose do Rio Preto, São José do Rio Preto, SP, Brasil.

2. Hospital de Base de Sáo José do Rio Preto, Departamento de Anestesiologista, Coordenaçâo da Clínica da Dor, São Jose do Rio Preto, SP, Brasil.

3. Faculdade de Medicina de São Jose do Rio Preto, Departamento de Enfermagem, Coordenação da Pós-Graduação em Enfermagem, São José do Rio Preto, SP, Brasil.

4. Faculdade de Medicina de Sấo José do Rio Preto, Departamento de Ciências Neurológicas, Clínica da Dor, São José do Rio Preto, SP, Brasil.

Submitted on March 12, 2019.

Accepted for publication on May 20, 2019.

Conflict of interests: none - Sponsoring sources: Fontes de fomento: Bolsa de Iniciaçấo Cientifica PIBIC/FAMERP.

Correspondence to:

Avenida Brigadeiro Faria Lima 5416

Departamento de Ciências Neurológicas

15090-000 São Jose do Rio Preto, SP, Brasil.

E-mail: marielzamartins@famerp.br

(C) Sociedade Brasileira para o Estudo da Dor
CONCLUSION: The pain had a negative influence on the quality of life and impact on the functionality of the elderly studied in the Pain Clinic

Keywords: Chronic pain, Health of the elderly, Quality of life.

\section{RESUMO}

JUSTIFICATIVA E OBJETIVOS: A dor crônica é uma das condiçóes mais comuns encontradas pelos profissionais de saúde; e nos idosos está associada à substancial mobilidade reduzida, esquiva de atividades, depressão, comprometimento do sono e isolamento. $\mathrm{O}$ objetivo deste estudo foi verificar o impacto da dor crônica na funcionalidade e na qualidade de vida de idosos. MÉTODOS: Trata-se de um estudo descritivo, transversal, exploratório com amostra de 20 pacientes pertencentes à Clínica da Dor do Hospital de Base de São José do Rio Preto. Para os dados comparativos foram avaliados pelos mesmos instrumentos 20 pacientes com idade inferior a 60 anos. Os instrumentos utilizados foram: entrevista semiestruturada contendo questóes sobre aspectos sensoriais, impacto emocional, impacto funcional, sono, atitudes e crenças, enfrentamento, tratamento, expectativa e objetivos e recursos. Para avaliar a qualidade de vida foi utilizado o questionário World Health Organization Quality of Life Assessment for Older Adults e, para avaliar a capacidade funcional da vida diária, a escala de atividades física e instrumental da vida diária "OARS". A dor, por sua vez, foi avaliada pelo Inventário Breve de Dor.

RESULTADOS: Foi observada diferença significativa entre os domínios de habilidades sensoriais, autonomia e intimidade $(\mathrm{p}<0,05)$ em que o grupo analisado apresentou piores valores que o controle, enquanto este último grupo apresentou pior valor no domínio de morte e morrer. Além disso, houve diferença estatística entre os grupos na atividade instrumental da vida diária e entre a intensidade da dor.

CONCLUSÁO: A dor acarretou influência negativa na qualidade de vida e afetou a funcionalidade dos idosos pesquisados na clínica da dor.

Descritores: Dor crônica, Qualidade de vida, Saúde do idoso.

\section{INTRODUCTION}

The aging of the population is an unquestionable event that grows over the years. According to the World Health Organization (WHO) ${ }^{1}$, it is estimated that in 2020 the number of people over the age of 60 will exceed the number of children up to 5 years and, by 2050, the population over 60 years will reach 2 billion individuals, which will account for a fifth of the planet's population. In this sense, one of the challenges of global public health will be to address the problems related to chronic pain 
(CP), considering that it is one of the most common conditions found in patients aged $\geq 65$ years $^{2}$.

$\mathrm{CP}$ is related to a substantial inability of elusive mobility of activity, falls, depression and anxiety, sleep disorders, and cocooning 2,3 . However, these negative effects are not restricted to the patient, but also encompass situations that disrupt family and social relationships, as well as changing the roles these individuals recognize themselves in society ${ }^{4}$.

Given that, it is observed that CP goes beyond a sensorial event, because it also includes affective elements (emotional responses to pain), cognitive (attitudes and beliefs about pain), behavioral (e.g., patients, family members or caregivers' behaviors in response to pain), besides sensory components (e.g., quality, location and time pattern $)^{5}$.

Differences in published researches about population, methods, and definitions, however, make it difficult to compare studies and make it impossible to determine the definitive prevalence of pain in the elderly ${ }^{3}$. This creates barriers for health professionals to develop skills to plan assessments and programs to manage CP in elderly patients.

Regarding the evaluation of the elderly with $\mathrm{CP}$, the literature provides little information, since it is recommended a comprehensive assessment with multidimensional measures, tools to verify the activities of daily living, collection of data of family/ caregivers, verification of attitudes and beliefs about the pain, review of comorbidities and drugs, among others. In this context, there are still important limitations based on evidence ${ }^{2}$.

The objective of this study was to evaluate the impact of CP on functionality and quality of life (QoL) of the elderly.

\section{METHODS}

A descriptive, cross-sectional, exploratory study with a quantitative approach. The sample analyzed had 20 patients (test group - TG), over 60 years. The sample size estimation considered a $95 \%$ of confidence level, the desired maximum error of three points and a mean, standard deviation, estimated in a pilot study, equal to 12.5 points, totalizing a minimum sample of 20 individuals. For the comparative data, 20 patients (control group - CG) below 60 years were evaluated by the same instruments, who also attended the Pain Clinic. Patients who did not agree to participate in the study by signing Free and Informed Consent Term (FICT) and those with sensory and limiting deficits screened by MiniMental test ${ }^{6}$ were excluded. The instruments used were a semi-structured interview containing questions about sensory aspects, emotional and functional impact, sleep, attitudes and beliefs, confrontation, treatment, expectation and objectives, and support resources, besides the collection of some personal data. Also, to assess the QoL, it was used the questionnaire World Health Organization Quality of Life Assessment for Older Adults (WHOQOL-OLD) ${ }^{7}$, containing 24 questions divided into six domains, including sensory ability, autonomy, past, present and future activities, social participation, death and dying, and intimacy. For the evaluation of the functional capacity of daily living, the Physical and Instrumental Activities of Daily Living Scale (OARS) ${ }^{8}$ was used, which analyzes the ability to perform activities autonomously, with assistance or totally disabled, with scores from zero to 2 , scaling from zero to 14 for each activity, and the lower the score, the greater is the individual's dependence. The pain was evaluated by the Brief Pain Inventory ${ }^{9}$ (BPI). This instrument included 15 items, divided into two parts: the first evaluates the intensity of pain (8 items), and the second evaluates the interference of pain in aspects of life (7 items): walking ability, sleep, work, relationship with other people and enjoying life on a numerical scale from zero (no pain) to 10 (worst possible pain).

The Research Ethics Committee of FAMERP approved the research project (Opinion no. 2,647,844), and it was conducted in the Ambulatory of the Pain Clinic, Hospital de Base (FUNFARME/FAMERP).

\section{Statistical analysis}

All the participants (TG and CG) were submitted to a single evaluation, and the data obtained were inserted into Excel spreadsheets. All statistical analyses were performed with a significance level $=0.05$. The Mann-Whitney test was used to compare both groups since the data were not parametric, and Pearson's Linear Correlation was used for the correlations.

\section{RESULTS}

Table 1 shows the sociodemographic characteristics of the studied samples.

Concerning the sensorial aspects in TG, 40\% $(n=8)$ reported decreased visual acuity and $32 \%(n=6)$ hearing loss. All the elderly in this group cited a decline in physical and health skills that impact their lives emotionally.

In relation to sleep, $57.5 \%(n=11)$, in the TG reported poor sleep quality, while $33.3 \%(n=7)$ of the CG reported the same $(\mathrm{p}<0.05)$.

In the TG, 65\% ( $n=13)$ believed that they will always depend on the drug and the most frequent attitude of $55 \%(n=10)$ is that the pain leads to rest and reduction of activities.

Concerning confrontation, in the TG 20\% ( $n=4)$ mentioned music, $35 \%(n=7)$ praying, $15 \%(n=3)$ cocooning, $10 \%(n=2)$ talking, $10 \%(n=2)$ stretching and $10 \%(n=2)$ entertain him/ herself.

In the studied groups, the diagnoses presented were CP related to osteoarticular diseases $(n=8)$, diabetic neuropathy $(n=6)$, pain syndrome after stroke $(n=6)$, polymyalgia rheumatica $(n=6)$, musculoskeletal disorders $(n=8)$, others $(n=6)$.

Regarding the analysis of variables related to QoL obtained by the WHOQOL-OLD, the means for each domain and the overall mean can be observed in figure 1 .

The analysis showed a statistically significant difference $(p<0.05)$ between the domains of sensory abilities $(p=0.002)$, autonomy $(\mathrm{p}=0.001)$ and intimacy $(\mathrm{p}=0.023)$, showing that TG presented worse values than CG.

The CG had more worries, concerns, and fears about death and dying than the TG, with a significant difference $(\mathrm{p}=0.038)$. 
Table 1. Sociodemographic characteristics of patients from both groups

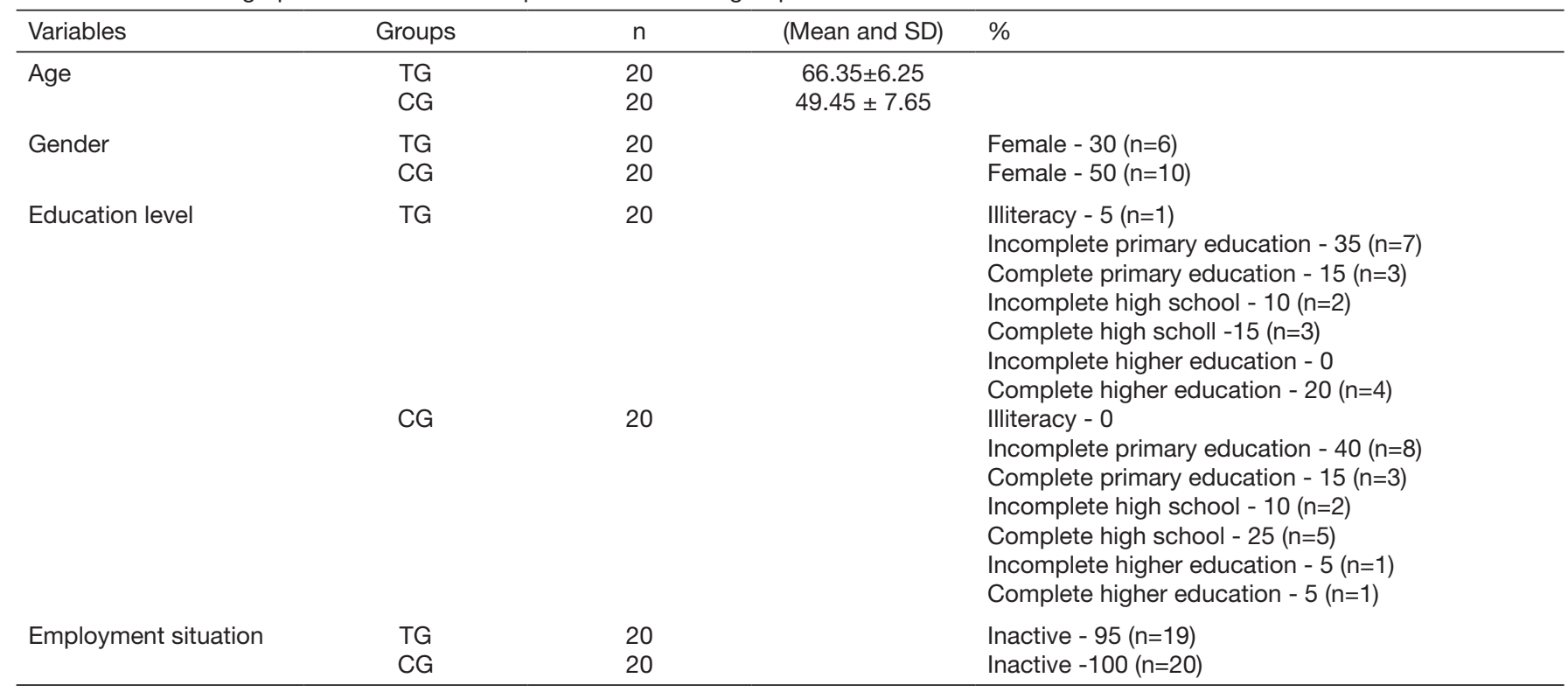

$\mathrm{TG}=$ test group; $\mathrm{CG}=$ control group.

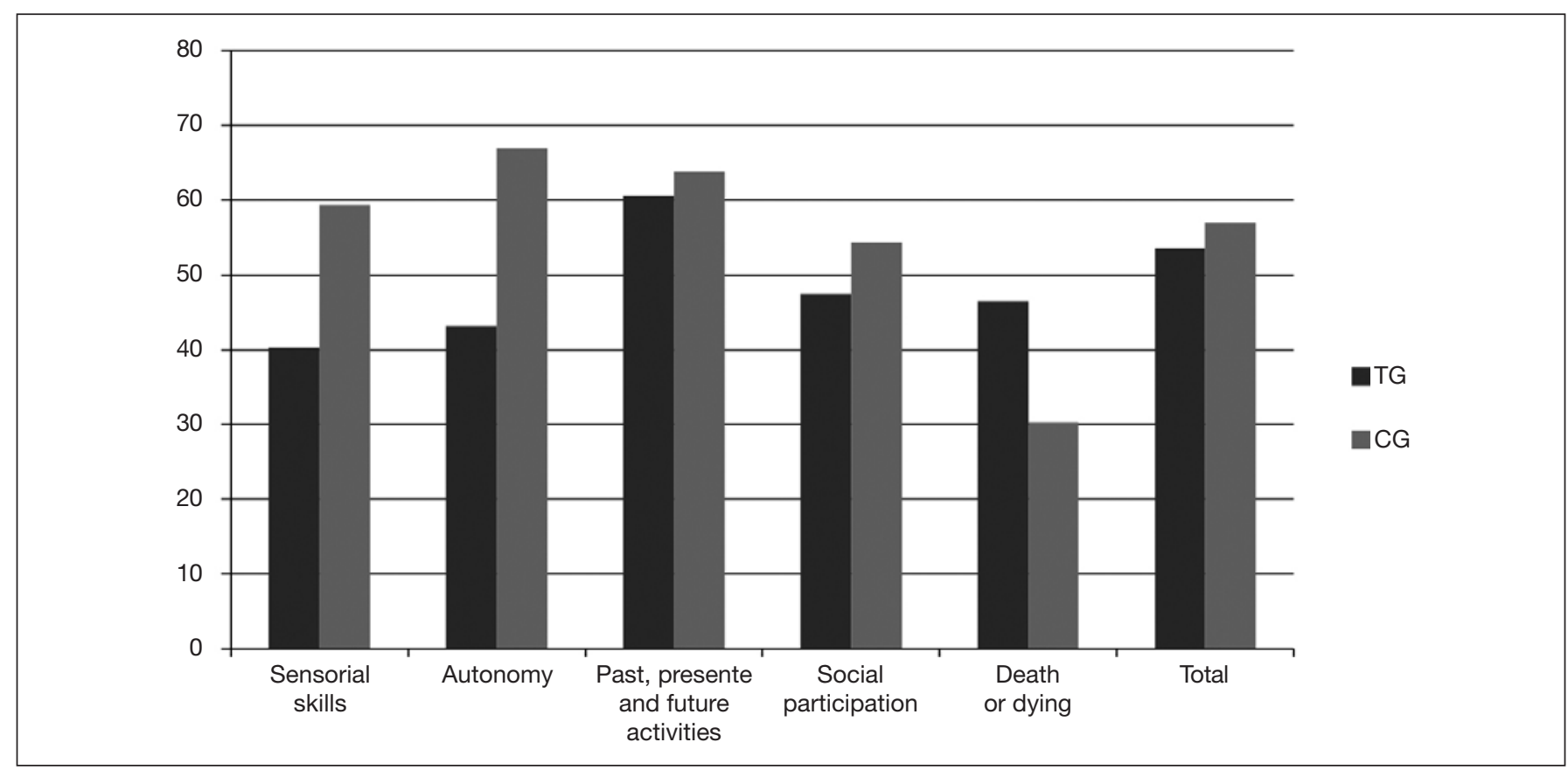

Figure 1. Mean scores of the domains related to the quality of life questionnaire by the WHOQOL-OLD in both groups $\mathrm{TG}=$ test group; $\mathrm{CG}=$ control group.

About the functional capacity for basic daily activities, obtained by the "OARS" scale, the mean scores can be observed in table 2. Regarding instrumental activities, $70 \%$ $(\mathrm{n}=14)$ of the elderly reported being unable to clean and housekeeping, while $15 \%(\mathrm{n}=3)$ claimed to need some help and $15 \%(n=3)$ performed the task without help. When asked about activities such as shopping, $25 \%(\mathrm{n}=5)$ considered themselves incapable of, $45 \%(n=9)$ need some help, and $30 \%(n=6)$ do it without help. In the evaluations of the activities of the physical scope, $70 \%(n=14)$ of the elderly stated that they need help to lie down and to get off the bed, while $30 \%(n=6)$ said they could do it without any help or support.

When asked if they have ever had problems to get to the toilet in time, $70 \%(n=14)$ answered yes, and 30\% ( $n=6)$ no.

In table 3 , the mean of the data obtained for the various parameters can be observed in the evaluation of the level of pain between the groups by the Brief Pain Inventory (BPI). 
Table 2. Average scores of the OARS physical and instrumental activity scale of daily life

\begin{tabular}{lcccc}
\hline Domains & Groups & $\mathrm{n}$ & (Mean and SD) & $\mathrm{P}$ value \\
\hline Instrumental activity of & TG & 20 & $8.65 \pm 2.98$ & $0.045^{\star}$ \\
daily life & CG & 20 & $10.8 \pm 2.71$ & \\
Physical activity of & TG & 20 & $11.5 \pm 1.53$ & 0.481 \\
daily life & CG & 20 & $11.7 \pm 1.81$ & \\
\hline
\end{tabular}

$\mathrm{TG}=$ test group; $\mathrm{CG}=$ control group; ${ }^{\mathrm{p}} \mathrm{p}<0.05$ = statistically significant difference (Mann-Whitney test); OARS = scale of physical and instrumental daily life activities.

Table 3. Brief Pain Inventory data analysis

\begin{tabular}{|c|c|c|c|}
\hline Parameters & $\begin{array}{c}\text { TG } \\
\text { Mean and } \\
\text { SD }(n=20)\end{array}$ & $\begin{array}{c}\text { CG } \\
\text { Mean and } \\
\text { SD }(n=20)\end{array}$ & $P$ value \\
\hline Pain intensity & $9.1 \pm 1.23$ & $8.6 \pm 2.26$ & $0.048^{*}$ \\
\hline \multicolumn{4}{|c|}{ Interference of pain in general activities } \\
\hline Mood & $6.2 \pm 3.50$ & $7.85 \pm 1.76$ & 0.250 \\
\hline Ability to walk & $7.2 \pm 3.60$ & $7.15 \pm 3.33$ & 0.942 \\
\hline Work & $8.8 \pm 2.44$ & $9.3 \pm 1.79$ & 0.662 \\
\hline $\begin{array}{l}\text { Relationship with other } \\
\text { people }\end{array}$ & $6.1 \pm 3.40$ & $5.45 \pm 3.13$ & 0.490 \\
\hline Sleep & $7.6 \pm 2.95$ & $7.9 \pm 1.65$ & 0.653 \\
\hline Ability to enjoy life & $7.2 \pm 2.90$ & $6.5 \pm 3.05$ & 0.430 \\
\hline
\end{tabular}

$\mathrm{TG}=$ test group; $\mathrm{CG}=$ control group; ${ }^{*} \mathrm{p}<0.05=$ statistically significant difference (Mann-Whitney test).

The Spearman's Correlation was used to compare the QoL data with the data of the instrumental activities of the pain scales and the interferences that the pain causes in the activities of the elderly. With a $p<0.05$ parameter, it can be observed that there were significant differences when the QoL was analyzed with the instrumental activity of daily life (IADL) $(\mathrm{R}=0.4861)$ and physical activity of daily life (PADL) $(\mathrm{R}=0.4946)$. Regarding the correlation pain versus $\mathrm{QoL}$, the statistical difference was of weak intensity $(\mathrm{r}=0.5863)$. When correlated to severe and moderate pain, no significant correlations were observed ( $r=0.3351$ and -0.2143 , respectively).

About the interference that pain has on QoL, in some aspects, there was significance in the areas of general activity $(R=-0.5955)$, work $(R=-0.6486)$ and personal relationship $(R=-0.6455)$.

Regarding the other aspects, mood, walking ability, sleep, and the ability to enjoy life, no correlations were found. Another correspondence observed, when analyzed, was the QoL with the patient's pain site $(\mathrm{R}=-0,4549)$.

\section{DISCUSSION}

The sample showed a predominance of males $(70 \%)$. This may be related to a devaluation of self-care and health ${ }^{10}$. As to the education level of the elderly, $20 \%(n=4)$ have completed higher education, which allowed to observe that, as in the study of Miranda and Banhato ${ }^{11}$, there was an increase in the elderly population with greater academic knowledge ${ }^{12}$. However, in this study, it can be observed that even with a higher education level, the CP had a great negative influence on the QoL of the studied population.
When analyzing the QoL data of the elderly by the WHOQOL-OLD questionnaire, it was observed that there were statistical differences in the domains of sensory ability, autonomy, intimacy and death and dying, the latter being more prevalent in the CG.

In the context of autonomy and intimacy, as people get older, they tend to need more help, whether from family members or caregivers. In this sense, imperative forms tend to stand out, leaving no room for negotiation with the desires that the elderly have, that is, the freedom to make decisions about their own life ends up becoming more and more reduced ${ }^{13}$, even causing a loss of self-esteem ${ }^{14}$. The result is that the older social group shows worse results, as observed in the research when compared to a young adult population. Also, the difference between the groups in sensory ability may correspond to the regression of the senses as age passes, with hearing and visual loss being the most mentioned ${ }^{15}$. Cavazzana et al. ${ }^{16}$ reported that impaired sensory functioning affects the QoL of the elderly by influencing how they experience the environment and react to stimuli and limit social activities - facts that can lead to isolation and depression.

On the other hand, groups under the age of 60 showed greater concern regarding the death and dying domain. This may be related to the fact that the 35 to the 60-year old group have higher rates of anxiety and depression that harm the $\mathrm{QoL}^{17}$. Given this, one can assume that these emotional and emotional health aspects have a great influence on this type of thinking.

A recent study ${ }^{18}$ reported that young adult and adult patients with hematologic and CP diseases experienced psychological distress, living with future uncertainty regarding their cure and fear of death, thus negatively affecting the QoL. Therefore, in this study, the authors suggested the need for age-specific psychological interventions designed to address this fear.

When analyzing the total QoL, we can observe a statistical difference between the groups analyzed $(p=0.008)$, since the overall mean of the TG questionnaire was 53.55 while the CG was 56.98. Therefore, we noticed a transformation in the social, psychological, and physical conditions of the elderly as the years go by, which undermine their well-being.

Ferretti et al. ${ }^{19}$ mentioned that pain interferes with people's perception of their own lives and, because of this, it requires appropriate actions aimed at well-being and control, reducing pain complaints to improve functional capacity, QoL and development of preventive strategies that help improve the health of these individuals ${ }^{18}$.

In the evaluation of "OARS," there was a difference between the groups in the IADL. This information corroborates another surve ${ }^{19}$ since the assessed activities, such as going to distant places that require the use of public transportation, or shopping, requires great physical and cognitive integrity. It was concluded that the progressive loss of this integrity implies a greater need for help or even lack of interest in performing some tasks.

However, pain also ends up being a parameter for the evaluation of the QoL of the elderly since it often stimulates uncomfortable and limiting situations ${ }^{20}$. Thus, the analysis of the intensity of pain ends up being fundamental to ascertain its influence in the way of life of the patient. 
The older population has higher pain intensity ${ }^{21.22}$, which is observed in the study, since the average pain of the group over 60 years falls within the maximum pain scores, while the CG, below 60 years, falls in the moderate pain, which is weaker compared to the previous one. In addition to this high pain scale, it can be observed that the elderly have a very long average time of pain $(8.75 \pm 4.59$ years), making the index of patients with CP very high, as in others studies ${ }^{21.23}$. The absence of statistical difference between pain interference for various activities between the groups is because pain tends to be limiting for any person $^{24}$. That is, regardless of age, the pain has negative interference in the performance of tasks, such as walking, relating, working, among others.

Thus, it is necessary to evaluate the physical and psychological components, the personal history, social aspects, beliefs so that all professionals can understand how individuals perceive their pain and adapt to it.

\section{CONCLUSION}

This study shows that CP had a negative influence on the QoL of the elderly population, with an impact on their functionality and autonomy.

\section{REFERENCES}

1. “Ageing well” must be global priority. Cent Eur J Public Health. 2014;22(4):265.

2. Reid MC, Eccleston C, Pillemer K. Management of chronic pain in older adults. BMJ. 2015;13(3):532-8.

3. Cornally N, McCarthy G. Persistent pain: the help-seeking behavior, attitudes, and beliefs of older adults living in the community. Pain Manag Nurs. 2011;12(4):206-17.

4. Marini AM, Martins M, Forni JE, Araujo Filho GM. Papéis ocupacionais e qualidade de vida em indivíduos com dor crônica. Ciência em Movimento - Reabilitação e Saúde. 2017;38(19):119-26.

5. Morís G, Wood L, Fernández-Torrón R, González-Coraspe JA, Turner C, Hilton-Jones $\mathrm{D}$ et al. Chronic pain has a strong impact on quality of life in facioscapulohumeral muscular dystrophy. Muscle Nerve. 2018;57(3):380-7.
6. Folstein MF, Folstein SE, McHugh PR. "Mini-mental". A practical method for grading the cognitive state of patients for the clinician. J Psychiatr Res. 1975;12(3):189-98.

7. Fleck MP, Chachamovich E, Trentini C. Development and validation of the Portuguese version of the WHOQOL-OLD module. Rev Saude Publica. 2006;40(5):785-91.

8. Fillenbaum GG, Smyer MA. The development, validity and reliability of the OARS multidimension functional assessment questionnaire. J Gerontol. 1981;36(4):428-34.

9. Ferreira KA, Teixeira MJ, Mendonza TR, Cleeland CS. Validation of brief pain inventory to Brazilian patients with pain. Support Care Cancer. 2010;19(4):505-11.

10. Figueiredo W. Assistência à saúde dos homens: um desafio para os serviços de atenção primária. Ciên Saúde Coletiva. 2005;10(1):105-9.

11. Miranda LC, Banhato EF. Quality of life in elderly people: the influence of the participation in groups. Psicol Pesq. 2008;2(1):69-80.

12. Dawalibi NW, Goulart RM, Prearo LC. [Factors related to the quality of life of the elderly in programs for senior citizens]. Cienc Saude Colet. 2014;19(8):3505-12. Portuguese.

13. Sanchez MA. Dependency and its implication to lost autonomy: study of the old age representations from a Geriatrics Ambulatory Unit. Textos Envelhecimento. 2000;3(3):35-54.

14. Irigaray TQ, Trentini CM. Qualidade de vida em idosas: a importância da dimensão subjetiva. Estud Psicol. 2009,26(3):297-304.

15. Nunes VM, Menezes RM, Alchieri JC. Avaliaçăo da qualidade de vida em idosos institucionalizados no município de Natal, Estado do Rio Grande do Norte. Acta Scientiarum. Health Sciences Maringá. 2010,32(2):119-26.

16. Cavazzana A, Röhrborn A, Garthus-Niegel S, Larsson M, Hummel T, Croy I. Sensory-specific impairment among older people. An investigation using both sensory thresholds and subjective measures across the five senses. PLoS One. 2018;13(8):e0202969.

17. Almeida FC, Castilho AC, Cesarino CB, Ribeiro RC, Martins MR. Correlação entre dor neuropática e qualidade de vida. BrJP. 2018;1(4):349-53.

18. Hlubocky FJ, Muffly LS, Gomez JX, Breitenbach K, Cella D, McNeer JL, et al. Death anxiety, psychological distress, and quality of life (QOL) in adolescent and young adult (AYA) cancer patients with hematologic malignancies in early survivorship. J Clin Oncol. 2016;34(14 Suppl):10073-10073.

19. Ferretti F, Castanha AC, Padoan ER, Lutinski J, Silva MR. Quality of life in the elderly with and without chronic pain. BrJP. 2018;1(2):111-5.

20. Freitas RS, Fernandes MH, Coqueiro RS, Reis WJ, Rocha S, Brito A. Capacidade funcional e fatores associados em idosos: estudo populacional. Acta Paul Enferm. 2012;25(6):933-9.

21. Dellaroza MS, Pimenta CA, Duarte YA, Lebrāo ML. [Chronic pain among elderly residents in São Paulo: prevalence, characteristics, and association with functional capacity and mobility (SABE Study)]. Cad Saude Publica. 2013;29(2):325-34. Portuguese.

22. Pereira LV, de Vasconcelos PP, Souza LA, Pereira Gde A, Nakatani AY, Bachion MM. Prevalence and intensity of chronic pain and self-perceived health among elderly people: a population-based study. Rev Lat Am Enfermagem. 2014;22(4):662-9. English, Portuguese, Spanish.

23. Circular Normativa. A Dor como $5^{\circ}$ sinal vital. Registo sistemático da intensidade da Dor; No 09/DGCG - 2003

24. Garbi Mde O, Hortense P, Gomez RR, da Silva Tde C, Castanho AC, Sousa FA. Pain intensity, disability and depression in individuals with chronic back pain. Rev Lat Am Enfermagem. 2014;22(4):569-75. English, Portuguese, Spanish. 